\title{
MONITORING THYROID HORMONES, SOME OF OXIDATIVE STRESS MARKERS AND BIOCHEMICAL CHANGES DURING THE EARLY AND MID STAGE OF LACTATION IN DAIRY COWS
}

\author{
GHADA A.E. MOHAMED and GAADEE H.I. M \\ Biochemistry and Nutritional Deficiency Diseases Unit, Animal Health Research Institute, Assiut Branch, Agriculture \\ Research Center, Egypt.
}

Received: 26 March 2019; $\quad$ Accepted: 30 April 2019

\begin{abstract}
This study aimed to compare changes in biomarkers of nutrient metabolism, thyroid hormones and oxidative stress parameters present during the early (EL) and mid-lactation (ML) stages in dairy cows reared under the hot summer conditions at Assiut city, Upper Egypt. Blood serum of twenty nine multiparous clinically healthy lactating Holstein Fresien cows (16 early lactating and 13 mid lactating cows) belonged to a private farm located under the same temperatures and living conditions were used in this study. Cows of ML had significantly lower values $(\mathrm{P}<0.05)$ than those of EL stage for glucose and cholesterol concentrations and also non-significantly differences in total protein, albumin and triglycerides $(\mathrm{P}>0.05)$. Similarly, non-significance differences $(\mathrm{P}>0.05)$ were found between the two lactation stages for thyroid hormones (Triiodothyronine, Thyroxine). For oxidants/antioxidant parameters, ML cows had significantly decreased values $(\mathrm{P}<0.05)$ for Superoxide dismutase and significantly increased values $(\mathrm{P}<0.05)$ for Glutathione $S$ - Transfereas activities than those of EL as well as non-significantly differences $(\mathrm{P}>0.05)$ for Malondialdehyde concentrations and catalase activity. Pearson's correlation coefficients between the metabolic parameters, thyroid hormones and oxidative indices in early and mid-stages of lactation showed different positive and also negative correlations. Can be concluded that this study gives evidence that the lactating cows undergo a substantial oxidative stress that related to metabolic and physiological adaptation during early lactation to mid lactation stages under the under the influence of high temperature conditions at Upper Egypt.
\end{abstract}

Key words: Thyroid hormones- Lactation- Oxidative stress- antioxidant- dairy cow.

\section{INTRODUCTION}

The lactation periods in dairy cows are especially critical and present considerable physiological challenges to homeostasis by imposing significant metabolic stressors that may contribute to the onset of diverse disorders (Castillo et al., 2005). Lactation causes negative energy balance and high mobilization of lipids from body fat reserves immediately before and after parturition as well as during the first stage of lactation in dairy cows (Reist et al., 2002), either in ewes leading to decline in animal productive and reproductive performance (Morgante et al., 2012). Due to these metabolic stresses which severely influence animal welfare causing so called production diseases like ketosis, hypocalcaemia (Ceciliani et al., 2018) or fatty liver and lipogenesis in the liver (Šamanc et al., 2010) rather than imbalance in hepatic

Corresponding author: Dr. GHADA A.E. MOHAMED

E-mail address: dr_kada2012@yahoo.com

Present address: Biochemistry and Nutritional Deficiency Diseases Unit, Animal Health Research Institute, Assiut Branch, Agriculture Research Center, Egypt. carbohydrate (Goff and Horst, 1997). This conditions results in free radical generation exceeding than body's antioxidant production capacity and oxidative stress development (Lamp et al., 2015; Koch et al., 2016; Ceciliani et al., 2018 and Putman et al., 2018) and disrupting inflammatory and immune functions (Contreras and Sordillo, 2011). Therefore, the evaluation of blood redox homeostasis has increasingly contributed to the knowledge of the processes involved in reproductive and metabolic status of dairy herds (Bernabucci et al., 2002; Castillo et al., 2012).

Adaptation of the endocrine system during the lactation period, primarily the thyroid gland is the key factor in maintaining metabolic balance Since, thyroid hormones play an important role in the ketosis pathogenesis (Djokvic et al., 2014), their impairment is an indicative parameter for these metabolic stresses.

Environmental conditions during hot summer in Egypt imposing direct or indirect effects on physiology, metabolism, hormonal, and immunity 
system (Marai et al., 1999), hence, heat stress may be responsible for oxidative stress observed in lactating dairy cows (Nardone et al., 2006) which involves changes in post absorptive lipid, carbohydrate, and amino acid utilization (Lamp et al., 2015).

Therefore, the goal of this study was to document changes in biomarkers of nutrient metabolism, thyroid hormones and oxidative stresses present during the early and mid-lactation stages in dairy cows reared under the hot summer conditions in Assiut city, Upper Egypt.

\section{MATERIALS AND METHODS}

\section{Animals:}

This study was carried out on 29 multiparous cows (4-6 years) belonged to a private farm at Assiut city feeded Barseem Hegazzy, silage, dried grass and concentrate mixture. ( $5 \mathrm{Kg} / \mathrm{head} /$ day $)$. Water was supplied ad libitum, kept under ambient temperature range from $40^{\circ}-45^{\circ}$. Animals were clinically healthy, with history of no metabolic or reproductive disturbances showing negative milk California Mastitis Test (CMT) APH, (1978). Where they were divided into 2 groups; the first $(\mathrm{N}=16)$ was in early lactation period, 20-100 days (EL) and the second $(\mathrm{N}=13)$ was in mid lactation period 100-150 days (ML).

\section{Sampling:}

Blood samples were collected into dry, clean centrifuge tubes without anticoagulant from jugular vein of all cows before morning feeding, left to clot at $4^{\circ} \mathrm{c}$ then centrifuged at $3000 \mathrm{rpm}$ for $20 \mathrm{~min}$ to obtain clear serum and kept in clean dry $1.5 \mathrm{ml}$ tubes (Eppendorf tubes) and stored at $-20{ }^{\circ} \mathrm{C}$ until used for biochemical analysis.

\section{Biochemical analysis:}

Serum proteins, glucose and lipids:

Total proteins (TP), albumin (Alb), glucose (Gluc), total cholesterol (Chol) and triglycerides (Trig) were determined by colorimetric methods using available commercial test kits after the method described by Henry et al. (1974).

\section{Thyroid hormones:}

Enzyme Immunoassay (EIA) was used for the quantitative determination of concentrations of Triiodothyronine (T3), and Thyroxine (T4) in blood serum using commercial test kits according to Wistom (1976) and manufacture instructions.

\section{Malondialdehyde (MDA):}

MDA levels were determined by colorimetric method according to Ohkawa et al. (1979), based on thiobarbuturic acid (TBA) reactivity.

\section{Superoxide dismutase (SOD):}

Concentration of (SOD) was measured according to Marklund and Marklund (1974). Briefly, 50 $\mu \mathrm{L}$ of serum, $75 \mathrm{mM}$ of tris-HCL buffer, $30 \mathrm{mM}$ of EDTA and $2 \mathrm{mM}$ of pyrogallol were added and absorbance waves were recorded at $420 \mathrm{~nm}$ for $30 \mathrm{~min}$. The activity of SOD is expressed as U $\backslash \mathrm{ml}$ of serum.

\section{Catalase activity (CAT)}

The (CAT) activity was measured in serum by the method of Beers and Sizer (1952). Decomposition of $\mathrm{H}_{2} \mathrm{O}_{2}$ was followed directly by the decrease in absorbance at $240 \mathrm{~nm}$, and the difference in absorbance per min was taken as a measure of the CAT activity. CAT activity was expressed as U/L of serum.

\section{Glutathion S- transferases (GST):}

The of activity (GST) was measured according to the method of (Habig et al., 1974).

\section{Statistical analysis:}

The packaged SPSS program for windows version 10.0.1 (SPSS, Chicago, IL, USA) was used for statistical analysis according to SPSS (1999). Data were analyzed using one-way analysis of variance (ANOVA) and expressed as mean \pm standard error (SE). Differences between groups were determined by means of Student's $t$-test. Pearson's correlation $(r)$ was performed on the paired data obtained by the individual cases. Significance level was set at $\mathrm{P}<0.05$.

\section{RESULTS}

Mean values $( \pm \mathrm{SE})$ of the biochemical parameters are shown in Table 1. Significance differences was shown between two stages of lactation, where the mid lactation stage had a lower values than the early lactation stage for glucose and total cholesterol concentrations $(\mathrm{P}<0.05)$. Non-statistical significance differences $(\mathrm{P}>0.05)$ were found between the two lactation stages for total protein, albumin and triglycerides.

Similarly, non-significance differences $(\mathrm{P}>0.05)$ were found between the two lactation stages for thyroid hormone (T3 and T4) as shown in table 2.

Mean values $( \pm$ SE) of oxidants and antioxidant parameters are shown in Table 3. A significance differences was shown between two stages of lactation, where the mid lactation stage had a lower values $(\mathrm{P}<0.05)$ for $\mathrm{SOD}$ and higher values $(\mathrm{P}<$ $0.05)$ for GST activities than the early lactation stage. Non-significance differences $(\mathrm{P}>0.05)$ were found between the two lactation stages for MDA concentrations and catalase activity. 
Pearson's correlation coefficient between all parameter measured in early stage of lactation. Were summarized in (Table 4).

Pearson's correlation coefficient between all parameter measured in mid stage of lactation. Were summarized in (Table 5).
Pearson's correlation coefficients at confidence interval $95 \%$ between the metabolic parameters, thyroid hormones and oxidative indices in early and mid-stages of lactation illustrated different positive and also negative correlations table 4,5 .

Table 1: Mean values of some biochemical parameters during two different stages of lactation.

\begin{tabular}{cccl}
\hline Parameters & Early lactation & Mid lactation & P value \\
\hline Total Proteins $(\mathbf{g} / \mathbf{d l})$ & $9.151 \pm 0.398$ & $8.444 \pm 0.468$ & 0.2571 \\
\hline Albumin $(\mathbf{g} / \mathbf{d l})$ & $3.358 \pm 0.171$ & $3.103 \pm 0.278$ & 0.4230 \\
\hline Glucose $(\mathbf{m g} / \mathbf{d l})$ & $35.19 \pm 2.602$ & $27.18 \pm 2.402$ & $0.0350^{*}$ \\
\hline Cholesterol $(\mathbf{m g} / \mathbf{d l})$ & $147.0 \pm 10.96$ & $112.7 \pm 11.00$ & $0.0373^{*}$ \\
\hline Triglycerides $(\mathbf{m g} / \mathbf{d l})$ & $27.54 \pm 1.704$ & $23.37 \pm 1.674$ & 0.0964 \\
\hline
\end{tabular}

Data are expressed as mean \pm SE of 29 samples

Statistical significant value $=(\mathrm{P}<0.05)$

Table 2: Mean values of thyroid hormones during two different stages of lactation.

\begin{tabular}{lccc}
\hline Parameters & Early stage & Mild stage & P value \\
\hline T3 $(\mathbf{n g} / \mathbf{d l})$ & $80.48 \pm 5.108$ & $83.20 \pm 5.152$ & 0.7136 \\
\hline T4 $(\boldsymbol{\mu g} / \mathbf{d l})$ & $6.388 \pm 0.526$ & $6.746 \pm 0.610$ & 0.6584 \\
\hline
\end{tabular}

Data are expressed as mean \pm SE of 29 samples

Statistical significant value $=(\mathrm{P}<0.05)$.

Table 3: Mean values of oxidant /antioxidant parameters during two different stage of lactation.

\begin{tabular}{cccc}
\hline Parameters & Early lactation & Mid lactation & P value \\
\hline MDA $(\mathbf{n m o l} / \mathbf{m L})$ & $16.60 \pm 1.550$ & $14.95 \pm 2.211$ & 0.5347 \\
\hline SOD $(\mathbf{U} / \mathbf{L})$ & $82.99 \pm 3.021$ & $67.89 \pm 5.174$ & $0.0138^{*}$ \\
\hline CAT (U/L) & $334.2 \pm 53.17$ & $279.5 \pm 39.67$ & 0.4357 \\
\hline GST (U/L) & $1.536 \pm 0.278$ & $2.471 \pm 0.283$ & $0.0270^{*}$ \\
\hline
\end{tabular}

Data are expressed as mean \pm SE of 29 samples

Statistical significant value $=(\mathrm{P}<0.05)$.

Table 4: Pearson's correlation coefficients for the all determining parameters in early stage of lactation.

\begin{tabular}{|c|c|c|c|c|c|c|c|c|c|c|}
\hline & Alb & Gluc & Chol & Trig & T3 & T4 & MDA & SOD & CAT & GST \\
\hline $\mathbf{T P}$ & 0.445 & 0.522 & -0.282 & 0.162 & 0.195 & -0.105 & 0.310 & -0.211 & -0.09 & -0.030 \\
\hline Alb & & 0.234 & -0.025 & 0.344 & 0.171 & 0.120 & 0.214 & -0.571 & -0.456 & -0.045 \\
\hline Gluc & & & 0.295 & 0.487 & 0.123 & -0.026 & 0.459 & -0.108 & 0.352 & 0.224 \\
\hline Chol & & & & 0.169 & -0.041 & -0.217 & 0.113 & -0.030 & 0.553 & 0.102 \\
\hline Trig & & & & & 0.196 & 0.475 & 0.483 & -0.083 & 0.425 & 0.134 \\
\hline T3 & & & & & & -0.087 & 0.226 & -0.260 & 0.021 & 0.095 \\
\hline T4 & & & & & & & -0.225 & 0.166 & 0.078 & -0.395 \\
\hline MDA & & & & & & & & 0.033 & 0.256 & 0.468 \\
\hline SOD & & & & & & & & & 0.278 & 0.104 \\
\hline CAT & & & & & & & & & & 0.272 \\
\hline
\end{tabular}

Pearson's correlation coefficients at confidence interval 95\% 
Table 5: Pearson's correlation coefficients for the all determining parameters in mid stage of lactation

\begin{tabular}{|c|c|c|c|c|c|c|c|c|c|c|}
\hline & ALB & Gluc & Chol & Trig & T3 & T4 & MDA & SOD & CAT & GST \\
\hline TP & 0.578 & 0.027 & 0.599 & -0.170 & 0.306 & 0.363 & -0.057 & 0.054 & -0.277 & 0.241 \\
\hline ALB & & 0.128 & 0.447 & 0.138 & 0.261 & 0.105 & -0.270 & -0.036 & -0.150 & 0.390 \\
\hline Gluc & & & 0.359 & 0.136 & 0.073 & 0.381 & -0.172 & 0.227 & -0.318 & 0.272 \\
\hline Chol & & & & -0.37 & 0.257 & 0.291 & -0.239 & 0.126 & -0.245 & 0.196 \\
\hline Trig & & & & & 0.364 & 0.236 & 0.537 & 0.207 & 0.249 & -0.031 \\
\hline T3 & & & & & & 0.666 & 0.303 & 0.303 & 0.384 & -0.255 \\
\hline T4 & & & & & & & 0.032 & 0.445 & -0.111 & -0.294 \\
\hline MDA & & & & & & & & -0.116 & 0.607 & -0.097 \\
\hline SOD & & & & & & & & & 0.105 & 0.057 \\
\hline CAT & & & & & & & & & & -0.19 \\
\hline
\end{tabular}

Pearson's correlation coefficients at confidence interval 95\%

\section{DISCUSSION}

This study highlighted the changes of metabolic, thyroid hormones and oxidative stress biomarkers between the early and mid-lactation period in dairy cows reared under summer high ambient temperature conditions. The present study indicated also that the metabolic and thyroid hormone indices are linked to changes of pro-oxidative and antioxidative parameters during the early and midlactation periods.

Significance differences in the biochemical parameters were shown between the two stages of lactation, where the mid lactation stage had a lower values than the early lactation stage for glucose and cholesterol concentrations. The changes in glucose level during the two stages of lactation might be explained by different factors such as reduced energy intake, because of the reduction in dry matter intake and increased thermoregulation and the negative effect of the heat on gluconeogenesis, as an endocrine acclimation to hot conditions. Lower values of glucose in cows in hot conditions were also observed by Ronchi et al. (2000), where they found a reduction of liver activity, so that the decrease in glucose concentration was explained by the negative effects of that reduction on gluconeogenesis. In addition decreased blood glucose levels may be attributed to intake of low energy diet (Bremmer et al., 2000), when high rate of glucose utilization in the mammary gland is required (Nazifi et al., 2008). But in our study.

Total cholesterol level in present study was higher in the early lactation than mid lactation stage which nearly the results of Piccione et al. (2009), where changes in lipid metabolism were found during pregnancy and lactation in most mammals (Roche et al., 2009). Conversely, triglycerides show nonsignificant $\mathrm{p}>0.05$ change between two lactation stages, where endocrine profile changes, lipolysis and lipogenesis are regulated to increase lipid reserve during pregnancy, and subsequently, these reserves are utilized following parturition and the initiation of lactation (Roche et al., 2009 and Nazifi et al., 2002).

The changes in glucose and cholesterol levels are not associated with significant changes in serum total proteins and albumin, which may reflect the consistency of hepatic effort during this period and adaptation of the studied cows to their nutritional environment. A similar finding was reported in a previous study (Castillo et al., 2005).

Thyroid hormones (T3, T4) provide a major mechanism that important to acclimation for lactation. Thyroid hormones had direct and indirect effects on most metabolic processes in the body and they needed to maintain metabolic rate and to modulate oxygen consumption and mitochondrial dynamics in all cells of the body (Berghout and Weirsinga, 1998). The current study recorded nonsignificant changes in T3 and T4 level between the early and mid-stage of lactation. The absence of variations in concentrations of these hormones may be associated with metabolic adaptation of lactating cows to lactation stress and especially under warmed climate in an attempt to reduce endogenous heat production (Kaneko, 1997).

Serum levels of total proteins, albumin, glucose, total cholesterol, and triglycerides are indicators of hepatic function (Djoković et al., 2011). Positive correlations were found between the some bioenergetic parameters levels in early and mid lactation stages may indicates that fat infiltration of the liver could develop in early or mid lactating cows. Possible changes in the liver function may have a harmful effect on their metabolism and a negative effect on milk production or reproduction 
by an increase of total serum protein during the lactation (Chamberlin et al., 2013).

With progress in lactation, high levels of dietary starch has been shown to induce oxidative stress in dairy cows, possibly due to cellular changes related to oxidative phosphorylation (Gabai et al., 2004). These situations may induce no clinical signs, but may consume energy and protein for production of immune responses, scavenging of free radicals and decrease the nutrient availability for production purposes, impairing the performance of the animal for the whole lactation period (Sordillo and Aitken, 2009).

Under physiological conditions, oxidants are neutralized by the antioxidant system (Omidi et al., 2017). Imbalance between increased oxidants production and reduced capacity of antioxidant system induces oxidative stress (Castillo et al., 2005, Gong and Xiao., 2016). Oxidative stress and antioxidant status depend on the stage of lactation, seasonal variations (Pilarczyk et al., 2012), and disease (Omidi et al., 2017). It has also been reported that heat stress, depending on the climatic changes, induces the free radicals production and reduction in plasma antioxidant activity (Megahed et al., 2008).

The present study revealed no significant different ( $p>0.05$ ) between two stages in mean value of serum MDA, however the observed note is higher than reported by others in clinically healthy lactating cows This coincide with Mohebbi-Fani et al. (2016), where they observed that the levels of MDA were not different between farms and among different lactation stages. These results are nearly compatible with Colakoglu et al. (2017), recorded high level of MDA in summer group compared to winter group cows. In addition Yatoo et al. (2014) observed significantly elevated levels of oxidative stress indices in lactating animals under different seasons than non-lactating animals indicating production stress in addition to climatic stress in lactating animals thus climate change and demand for milk production predisposes animals to oxidative stress.

The current study, proved statistically significant increase in SOD at early stage of lactation in contrast with Cigliano et al. (2014) observed higher level of concentration in mid lactation cow than early lactation.

The SOD initiates the antioxidant process, transforming ROS into hydrogen peroxide, which is neutralized by catalase, further it is to be considered that SOD enzyme is transient in its action and actively shows a spurt on spontaneous induction of stress which may possible until other homeostasis enzyme have removed the association ROS and vice versa (Petersen and Enghild, 2005). In the current study, there were non-significant changes in catalase activity between the two groups, which agree with the results of Sharma et al. (2011). However, we noticed significant differences between the mean values of SOD in the two stages of lactation cows. Higher serum SOD activity in early lactation might be due to physiological upgrading of this enzyme in an attempt to neutralize/mitigation of superoxide radical challenges and adaption of animals to oxidative stress in an attempt to improve the antioxidant status (Anil and Meenaxi, 2018).

Glutathione S- transferases (GST) are seleniumindependent enzymes that also utilize GSH for the reduction of different electrophilic substrates such as hydroperoxides or lipid peroxides (Wilce and Parker, 1994). This mechanism may be involved in the detoxification of ROS (Scha“ffer et al., 1988). The level of GST can be regarded as a marker of cell vulnerability to stress factors (Nørgaard et al., 2008). In the current study, early lactation cows had lower GST levels than mid lactation cows. This result may adjusted to the fact that GST is consumed in early lactation because it is used to increase lipid mobilization from the adipose tissue, and increases blood non steroid fatty acid (NEFA) and betahydroxybutyrate (BHB) in early lactation cows (Jindal and Ludri, 1994).

The possibility that metabolic activity may determine oxidant status is supported by the detected correlations depending on the physiological condition. Correlations between most metabolites are dependent on energy balance (Castillo et al., 2005). The positive correlation between circulating thyroid hormones concentrations and metabolic variables is well known in cattle and provide some indication of postpartum disease risk and can be useful as a herd monitoring tool (Đoković et al., 2016). The positive correlations between thyroid hormones and some metabolites during mid lactation as indicator of energy coincide with Capuco et al. (2001) and Cassar-Malek et al. (2001), but incompatible with Nixon et al. (1988), where they mentioned negative correlation. This is supported by the fact that classifying cows according to metabolites levels can be of considerable help in detecting cows that would show certain metabolic changes in early lactation or develop a metabolic disease and, thus, produce less milk (Ospina et al., 2010, Cincović et al., 2012), due to poor adaptation to homeorhetic processes. Correlations among thyroid hormones and biochemical parameters suggest a relationship between thyroid hormones and predictors of lipomobilization. Monitoring of thyroid hormones, especially $\mathrm{T} 3$, could represent an important tool to evaluate the metabolism adaptation in dairy cows and in order to understand when regulatory mechanisms break through the physiological limits predisposing the cows to metabolic problems (Fiore et al., 2017). 
Lipoperoxide concentrations showed positive correlations with lipid metabolism indicators. The increase in the oxidative metabolism implies peroxidation of fatty acids leading to formation of lipid peroxides (Kankofer, 2001). The positive correlations detected between MDA and the metabolic parameters indicate that these metabolites are implicated in the formation of oxidative stress during the early lactation period. This is supported by the negative correlations between the metabolic activity and the antioxidant parameters during the same period. Similar results were obtained by Castillo et al. (2005) and Boudjellaba et al. (2018) who found correlations between the metabolic indices and the oxidant/antioxidant markers (MDA, SOD, CAT and GST).

As a conclusion, this study gives evidence that the lactating cows undergo a substantial oxidative stress that related to metabolic and physiological adaptation during early lactation to mid lactation stages under the hot summer conditions at Assiut city, Upper Egypt. And further investigation must be done to know how the stage of lactation responds dairy cows to heat stress and how the first change is occurring.

\section{REFERENCES}

Anil, M. and Meenaxi, S. (2018): A Review: Oxidative Stress during Lactation in Dairy Cattle. Dairy and Vet. Sci. J. 5(4): 555669.

APH (1978): "Standard Methods for Examination of Dairy. Products" 14th ed., American Public Health Association. Washington

Beers, Jr. RF, Sizer IW. (1952): A spectrophotometric method for measuring the breakdown of hydrogen peroxide by catalase. J Biol. Chem. 195:133-140.

Berghout, A. and Weirsinga, W. (1998): Thyroid size and thyroid function during pregnancy: An analysis. European J. Endocrinology. 138: 536-542.

Bernabucci, U.; Ronchi, B.; Lacetera, N. and Nardone, A. (2002): Markers of oxidative status in plasma and erythrocytes of transition dairy cows during hot season. J. Dairy Sci. 85:2173-2179.

Bremmer, D.R.; Trower, S.L.; Bertics, S.J.; Besong, S.A.; Bernabucci, U. and Grummer, R.R. (2000): Etiology of fatty liver in dairy cattle: effects of nutritional and hormonal status on hepatic microsomal triglyceride transfer protein. Journal of dairy science 83, 22392251

Boudjellaba, S.; Ainouz, L.; Tennah, S.; Temim, S. and Iguer-Ouada, M. (2018): Reproduction performance and blood biochemical parameters in dairy cows: Relationship with oxidative stress status. Veterinary world, 11(6), 883-888.
Capuco, A.V.; Wood, D.L.; Elsasser, T.H.; Kahl, S.; Erdman, R.A.; van Tassell, C.P.; Lefcourt, A. and Piperova, L.S. (2001): Effect of somatotropin on thyroid hormones and cytokines in lactating dairy cows during ad libitum and restricted feed intake, J. Dairy Sci., 84, 2430-2439.

Cassar-Malek, I.; Kahl, S.; Jurie, C. and Picard, C. (2001): Influence of feeding level during post weaning growth on circulating concentrations of thyroid hormones and extra thyroidal 5'deiodination in steers, J. Anim. Sci., 79, 2679-2687.

Castillo, C.; Hernández, J.; García Vaquero, M.; López Alonso, M.; Pereira, V.; Miranda, M.; Blanco, I. and Benedito, J.L. (2012): Effect of moderate $\mathrm{Cu}$ supplementation on serum metabolites, enzymes and redox state in feedlot calves. Research in Veterinary Science, 93, 269-274.

Castillo, C.; Hernandez, J. and Bravo, A. (2005): Oxidative status during late pregnancy and early lactation in dairy cows. The Veterinary Journal. 169: 286-292.

Ceciliani, F.; Lecchi, C.; Urh, C. and Sauerwein, H. (2018): Proteomics and metabolomics characterizing the pathophysiology of adaptive reactions to the metabolic challenges during the transition from late pregnancy to early lactation in dairy cows. Journal of proteomics, 178, 92-106.

Chamberlin, W.G.; Middleton, J.R.; Spain, J.N.; Johnson, G.C.; Ellersieck, M.R. and Pithua, $P$. (2013): Subclinical hypocalcaemia, plasma biochemical parameters, lipid metabolism, postpartum disease, and fertility in post parturient dairy cows. J Dairy Sci, 96: 70017013.

Cigliano, L.; Strazzullo, M.; Rossetti, C.; Grazioli, G. and Auriemma, G. (2014): Characterization of blood redox status of early and mid-late lactating dairy cows. Czech J Anim Sci 59(4): 170-181.

Cincović, R.M.; Belic, B.; Radojičić, B.; Hristov, S. and Đokovic, R. (2012): Influence of lipolysis and ketogenesis to metabolic and hematological parameters in dairy cows during per parturient period. Acta Vet. Beograd, 62: 429-444.

Colakoglu, H.E.; Yazlik, M.O.; Kaya, U.; Colakoglu, E.; Kurt, S.; Oz, B.; Bayramoglu, R.; Vural, M.R. and Kuplul, S. (2017): MDA and GSHPx activity in transition dairy cows under seasonal variations and their relationship with reproductive performance. J. Vet. Res., 61: 497-502.

Contreras, G.A. and Sordillo, L.M. (2011): Lipid mobilization and inflammatory responses during the transition period of dairy cows. Comparative Immunology, Microbiology and Infectious Diseases, 34, 281-289. 
Djoković, R.; Ilić, Z.; Kurćubić, V.; Petrović, M. and Doskovic, V. (2011): Functional and morphological state of the liver in Simmental dairy cows during transitional period. Rev Med Vet, 162: 574-579.

Djokvic, R.; Cincovic, M.; Kurcubic, V.; Petrovic, M.; Lalovic, M.; Jasovic, B. and Stanimirovic, $Z$. (2014): Endocrine and metabolic status of dairy cows during transition period, Thai. J. Vet. Med.,44, 59- 66.

Đoković, R.; Ilić, Z.; Kurćubić, V.; Petrović, M.; Cincović, M.; Lalović, M. and Jašović, B. (2016): Relationships between blood hormones and metabolites in simmental dairy cows during transition period and mid lactation. Macedonian Journal of Animal Science, 6(2).

Fiore, E.; Giambelluca, S.; Morgante, M.; Piccione, G.; Vazzana, I.; Contiero, B. and Gianesella, M. (2017): Changes in Thyroid Hormones Levels and Metabolism in Dairy Cows around Calving. Acta veterinaria, 67(3), 318-330.

Gabai, G.; Testoni, S.; Piccinini, R.; Marinelli, L. and Stradaioli, G. (2004): Oxidative stress in primiparous cows in relation to dietary starch and the progress of lactation. Animal Science 79 (1), 99-108.

Goff, J.P. and Horst, R.L. (1997): Physiological changes at parturition and their relationship 245 to metabolic disorders, J. Dairy Sci., 80, 1260-1268, 1997.

Gong, J. and Xiao, M. (2016): Selenium and antioxidant status in dairy cows at different stages of lactation. Biol Trace Elem Res. 2016, 171, 89-93

Habig, W.H.; Pabst, M.J. and Jakoby, W.B. (1974): Glutathione S-transferases: The first enzymatic step in mercapturic acid formation. J. Biol. Chem., 249: 7130-7139.

Henry, R.J.; Cannon, D.C. and Winkelman, J.W. (1974): Clinical chemistery, Priciples and techniques.4th Ed., Haroer \&Row; Hagerston M. D.

Jindal, S.K. and Ludri, R.S. (1994): Relationship between some circulating hormones, metabolites and milk yield in lactating crossbred cows and buffaloes. Asian-Aust J Anim Sci, 7: 239-248.

Kaneko, J.J. (1997): Thyroid function, In: Clinical Biochemistry of Domestic Animals. Eds. Kaneko, J. J; Harvey, J. W. and Bruss, M. L; 5th Ed. Academic press, London. pp. 571588.

Kankofer, M. (2001): The levels of lipid peroxidation products in bovine retained and non-retained placenta. Prostaglandins, Leukotrienes and Essential Fatty Acids 64, 33-36.

Koch, F.; Lamp, O.; Eslamizad, M.; Weitzel, J. and Kuhla, B. (2016): Metabolic response to heat stress in late-pregnant and early lactation dairy cows: implications to liver-muscle crosstalk. PloS one, 11(8), e0160912.

Lamp, O.; Derno, M.; Otten, W.; Mielenz, M.; Nürnberg, G. and Kuhla, B. (2015): Metabolic heat stress adaption in transition cows: Differences in macronutrient oxidation between late-gestating and early-lactating German Holstein dairy cows. PloS one, 10(5), $\mathrm{e} 0125264$.

Marai, I.F.M.; Habeeb, A.A.M. and Farghaly, H.M. (1999): Productive, physiological and biochemical changes in imported and locally born Friesian and Holstein lactating cows under hot summer conditions of Egypt. Tropical animal health and production, 31, 233-243.

Marklund, S. and Marklund, G. (1974): Involvement of the superoxide anion radical in the autoxidation of pyrogallol and a convenient assay for superoxide dismutase. European journal of biochemistry, 47(3), 469-474.

Megahed, G.A.; Anwar, M.M.; Wasfy, S.I. and Hammadeh, M.E. (2008): Influence of heat stress on the cortisol and oxidant-antioxidants balance during estrous phase in buffalo-cows (Bubalus bubalis): Thermo-protective role of antioxidant treatment. Reprod Dom Anim 2008, 43, 672-677.

Mohebbi-Fani, M.; Ansari-Lari, M.; Nazifi, S.; Abbasi, F. and Shabbooe, Z. (2016): Oxidative status and acute phase response in post-transition early-and mid-lactation Holstein cows and their correlations with some performance records. J Fac Vet Med Istanbul Univ, 42, 65-73, 2016.

Morgante, M.; Gianesella, M.; Casella, S.; Stelletta, C.; Cannizzo, C.; Giudice, E. and Piccione, $G$. (2012): Response to glucose infusion in pregnant and non-pregnant ewes: changes in plasma glucose and insulin concentrations, Comp. Clin. Pathol., 21, 961-965.

Nardone, A.; Ronchi, B.; Lacetera, N. and Bernabucci, U. (2006): Climatic effects on productive traits in livestock.Veterinary Research Communications. 30: 75-81.

Nazifi, S.; Saeb, M. and Ghavami, S.M. (2002): Serum lipid profile in Iranian fat-tailed sheep in late pregnancy, at parturition and during the post-parturition period, J. American Vet. Med. Association. 49: 9-12.

Nazifi, S.; Mhebbi-Fani, M.; Rowghani, E. and Behlood, M.R. (2008): Studies on the relationship Between Sub-Clinical Ketosis and Liver Injuries Within the First Two Months of Lactation Period in High Producing Iranian Holstein cows: International Journal of Dairy Science3, 2935.

Nixon, D.; Akasha, M.A. and Anderson, R.R. (1988): Free and total thyroid hormones in serum of 
Holstein cows, J. Dairy Sci., 1988, 71, 11521160.

Nørgaard, J.V.; Theil, P.K.; Sørensen, M.T. and Sejrsen, K. (2008): Cellular mechanisms in regulating mammary cell turnover during lactation and dry period in dairy cows. Journal of dairy science, 91(6), 23192327.

Ohkawa, H.; Ohishi, W. and Yagi, K. (1979): Anal. Biochmical, 95,351.

Omidi, A.; Fathi, M.H. and Parker, M.O. (2017): Alterations of antioxidant status in dairy cows during lactation and in the dry period. J Dairy Res 2017, 84, 49-53.

Ospina, PA.; Nydam, D.V.; Stokol, T. and Overton, TR. (2010): Association between the proportion of sampled transition cows with increased non-esterified fatty acids and $\beta$ hydroxybutyrate and disease incidence, pregnancy rate, and milk production at the herd level. J Dairy Sci, 93: 3595-3601.

Petersen, S.V. and Enghild, J.J. (2005): Extracellular superoxide dismutase: structural and functional considerations of a protein shaped by two different disulfide bridge patterns. Biomed. Pharmacother. 59, 175182.

Piccione, G.; Caola, G.; Giannetto, C.; Grasso, F.; Runzo, SC.; Zumbo, A. and Pennisi, P. (2009): $\quad$ Selected biochemical serum parameters in ewes during pregnancy, postparturition, lactation and dry period. Animal Science Papers and Reports. 27: 321-330.

Pilarczyk, B.; Jankowiak, D.; Tomza-Marciniak, A.; Pilarczyk, R.; Sablik, P.; Drozd, R.; Tylkowska, A. and Skolmowska, M. (2012): Selenium concentration and glutathione peroxidase (GSH-Px) activity in serum of cows at different stages of lactation. Biol Trace Elem Res 2012, 147, 91-96.

Putman, A.K.; Brown, J.L.; Gandy, J.C.; Wisnieski, L. and Sordillo, L.M. (2018): Changes in biomarkers of nutrient metabolism, inflammation, and oxidative stress in dairy cows during the transition into the early dry period. Journal of dairy science, 101(10), 9350-9359.

Reist, M.; Erdin, D.; Von Euw, D.; Tschuemperlin, K.; Leunberger, H.; Chilliard., H.; Hammon, M.; Morel, C.; Philopona, C.; Zbinder, Y.;
Kuenzi, N. and Blum, J.W. (2002): Estimation of energy balance at the individual and herd level using blood and milk traits in highyielding dairy cows, J. Dairy Sci.85, 33143327.

Roche, J.R.; Friggens, N.C.; Kay, J.K.; Fisher, M.W.; Stafford, K.J. and Berry, D.P. (2009): Invited review: Body condition score and its association with dairy cow productivity, health, and welfare. Journal of Dairy Science, 92, 5769-5801.

Ronchi, B.; Bernabucci, U.; Lacetera, N. and Nardone, A. (2000): Oxidative and metabolic status of high yielding dairy cows in different nutritional conditions during the transition period. Proc. 51stAnnu Mtg E.A.A. P Vienna, pp. 125 J. Dairy Sci. 76: 2812-2823.

Šamanc, H.; Stojic, V; Kirovski, D.; Jovanovic, M.; Cernescu, H. and Vujanac, I. (2010): Thyroid hormones concentrations during the mid-dry period: an early indicator of fatty liver in Holstein-Friesian Dairy Cows, J. Thyroid Res., 897602, 6 pp.doi:10.4061/2010/897602.

Sharma, N.; Singh, N.K.; Singh, O.P.; Pandey, V. and Verma, P.K. (2011): Oxidative Stress and Antioxidant Status during Transition Period in Dairy Cows. Asian-Aust. J. Anim. Sci. 479 $-484$

Schäffer, J.; Gallay, O. and Ladenstein, R. (1988): Glutathione transferase from bovine placenta. J Biolog Chem, 263, 17405-17411.

Sordillo, L.M. and Aitken, S.L. (2009): Impact of oxidative stress on the health and immune function of dairy cattle. Veterinary Immunology and Immunopathology, 128, 104-109

SPSS (1999): ANOVA in Sample Power Statistics, SPSS, Syntax Reference Guide for SPSS Base. SPSS Inc., 233 South Wacker Drive, Chicago, IL. pp 111-119.

Wilce, MC. and Parker, MW. (1994): Structure and function of glutathione S-transferases. Biochim Biophys Acta 1205: 1-18.

Wistom, G.B. (1976): Enzyme-Immunoassay. Clin. Chem. 22: 1243-1248

Yatoo, M.I.; Dimri, M. and Sharma, M.C. (2014): Seasonal changes in certain blood antioxidants in cattle and buffaloes. Indian $J$. Anim. Sci., 84(2): 173-176. 


\section{رصد هرمونات الغدة الدرقية، بعض ضغوط الأكسدة والتغيرات البيوكيميائية خلال مرحلة الحليب الاولى والوسطى فى الأبقار الحلابة \\ غادة عبل العظبيم محمد محمود ، هلى ابر/هيم مصطفى جعبلى}

E-mail:dr_kada2012@yahoo.com_Assiut University web-site: www.aun.edu.eg

هدفت هذه الدر اسة إلى مقارنة التغير ات في المؤشرات الحيوية لعملية التمثيل الغذائي وهرمونـات الغدة الدرقيـة والإجهاد التأكسدي

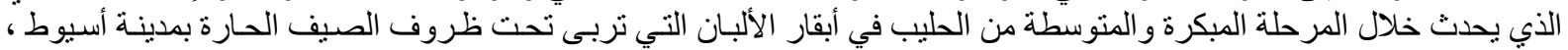

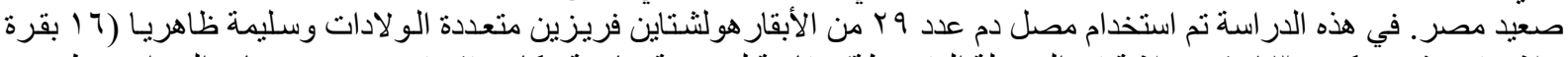

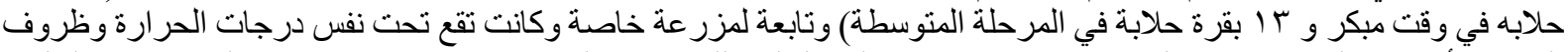

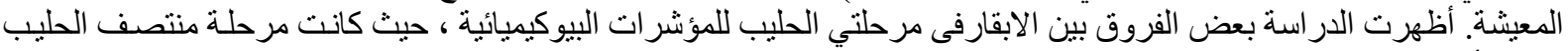

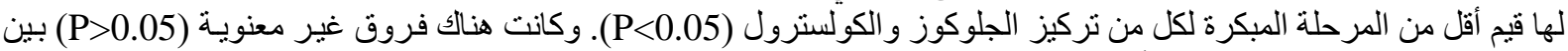

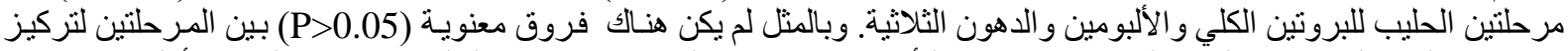

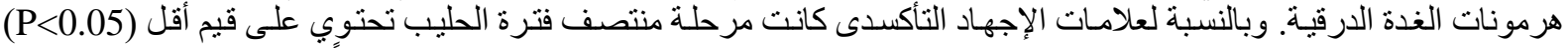

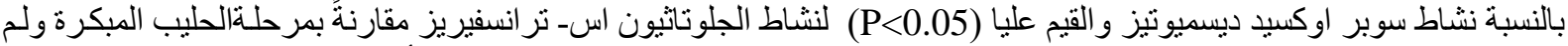

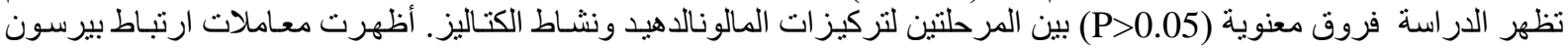

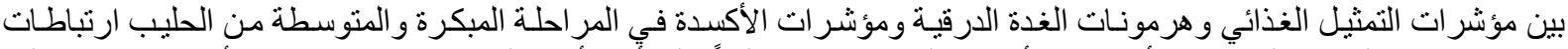

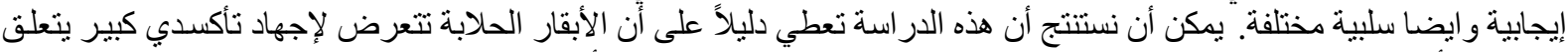

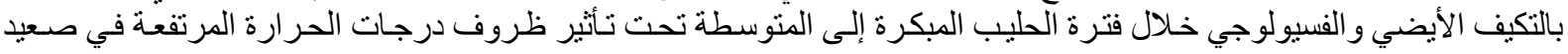

